https://doi.org/10.5817/OS2021-1-8

\title{
Jubileum českého slavisty a komparatisty
}

V roce 2021 uplynulo 6o let od narození významného českého slavisty a komparatisty prof. PhDr. Miloše Zelenky, DrSc., vedoucího Katedry slovanských jazyků a literatur na Pedagogické fakultě Jihočeské univerzity, člena vědeckých rad v ČR a SR a redakčních rad renomovaných vědeckých časopisů, autora knih a studií zachycených v prestižních databázích, pilného účastníka kongresů, konferencí a sympozií v celém světě.

V letech 1980-1985 jubilant vystudoval češtinu a dějepis na Filozofické fakultě Univerzity Karlovy, později zde pokračoval jako aspirant. Za svého učitele - kromě jiných - pokládal zejména literárního historika Vladimíra Štěpánka (1917-1991), který ho upoutal výkladem české literatury 19. století a dal mu metodologické základy oboru i vědomí vývojové kontinuity umění i vědy. Na Katedře české literatury a literární vědy Filozofické fakulty Karlovy univerzity působil po výkonu vojenské prezenční služby do roku 1991, kdy ji musel neoprávněně opustit, a rok strávil jako učitel na střední škole v Praze; od roku 1992 až dosud působí na Jihočeské univerzitě v Českých Budějovicích. Důležitým momentem pro jeho vědecký růst bylo setkání s prof. Slavomírem Wollmanem (1925-2012) a práce v obnoveném Slovanském ústavu AV ČR, kde byl i vedoucím Literárněvědného oddělení (1997-200o) a kde pracoval až do svého vynuceného odchodu, jakož i kontakt s prof. Zdeňkem Mathauserem (1920-2007). Jeho znalostí využil posléze Ústav pro soudobé dějiny AV ČR a jeho Výzkumné centrum pro studium vědy a oddělení dějin vědy, kde pracoval na projektech v letech 2003-2006; od roku 2012 dosud přednáší externě na Katedře kulturologie, od r. 2015 Ústavu etnologie a kulturních studií na FF UK v Praze. Vedoucím Katedry českého jazyka a literatury a později Katedry slovanských jazyků a literatur je od roku 2006.

Aspiranturu ukončil v Brně za vedení prof. Dušana Jeřábka a prof. Milana Kopeckého roku 1990, v Brně se také roku 1996 habilitoval pro obor dějiny a teorie dějiny slovanských literatur, doktorem věd se stal roku 2001 pro týž obor a profesorem roku 2004 v oboru Literární věda na Prešovské univerzitě. Od české literatury postupně přechází k srovnávacímu zkoumání slovanských literatur, metodologii literárněvědné slavistiky, literární komparatistiky, imagologie a areálových studií inspirován jejich brněnským modelem, pokračuje ve studiu dějin slavistiky, zejména wollmanovského směru, v literární vědě, edičně i odborně se věnuje také dílu Romana Jakobsona, Alberta Pražáka a Karla Krejčího. K jeho špičkovým pracím patří mimo jiné Literární věda a slavistika (Praha: Academia 2002), Komparatistika v kulturních souvislostech (České Budějovice: Jihočeská univerzita 2012), Comparative Literature and Area Studies (České Budějovice: Jihočeská univerzita 2012), Střední Evropa v literární a symbolické geografii 
(Nitra: UKF 2008); v roce 1996 publikoval na Masarykově univerzitě (s mým malým přispěním) originální knihu René Wellek a meziválečné Československo s podtitulem Ke kořenům strukturální estetiky. Svými studiemi zaplňuje zejména prestižní světové časopisy, mimo jiné World Literature Studies, Primerjalna književnost, Revue des Études slaves, Slavistična revija, Porównania, Slavia Occidentalis, Revue de la Littérature Comparée aj. Jeho dominantními tématy jsou literární komparatistika, světová literatura, ale neopomíjí ani své východisko, českou literaturu.

Menší studii by zaplnil seznam organizací a prestižních grémii, jichž je členem, mj. Společnost Dionýze Ďurišina, Komise pro dějiny slavistiky a Komise pro srovnávací dějiny slovanských literatur při Mezinárodním komitétu slavistů, Vědecká rada Filozofické fakulty Prešovské univerzity v Prešově (2004-2012), Vědecká rada Fakulty stredoeurópských štúdií Univerzity Konštantína Filozofa v Nitře (od roku 2008), Vědecká rada Filozofické fakulty Univerzity Konštantína Filozofa v Nitře (od roku 2002); je členem redakční rady časopisu World Literature Studies, redakční rady časopisu Kultúra a spoločnost’ vydávaného Fakultou stredoeurópských štúdií Univerzity Konštantína Filozofa v Nitře (od roku 2019 přejmenováno na Stredoeurópské rozhlady), redakční rady časopisu Slavica Nitriensia vydávaného Filozofickou fakultou Univerzity Konštantína Filozofa v Nitře, redakční rady časopisu Slavia Occidentalis (od roku 2012), redakční rady časopisu Świat Słowian (Białsko-Biala) od roku 2015. Významná je jeho role předsedy Společnosti Aloise Jiráska, s Moravou ho spojuje členství v Matici moravské, ve výboru Literárněvědné společnosti při AV ČR se sídlem v Brně; je také místopředsedou Slavistické společnosti Franka Wollmana, místopředsedou České asociace slavistů, členem redakční rady časopisu Opera Slavica vydávaného Filozofickou fakultou Masarykovy univerzity v Brně, v letech 2003-2004 byl členem celostátní komise pro DrSc. při MŠMT ČR, obor Teorie a dějiny slovanských literatur, je stálým členem komise pro DrSc. při SAV v Bratislavě, obor Teória a dejiny konkrétnych národnych literatúr a Teória a dejiny slovanských literatúr (od roku 2006), členem oborové doktorské rady (Literární komparatistika) při Ústavu slavistiky FF MU v Brně, členem oborové doktorské rady (Slovanská filologie) při Filozofické fakultě Univerzity Palackého v Olomouci, členem oborové doktorské rady (Literární věda) při Filozofické fakultě Prešovské univerzity v Prešově, členem oborové rady Pedagogické fakulty Univerzity v Hradci Králové - obor Teorie a dějiny české literatury ve studijním programu Filologie (2015-2018), členem Atestační komise pro Univerzitu Konštantína Filozofa v Nitře (2014-2018), členem Vědecké rady Pedagogické fakulty Jihočeské univerzity v Českých Budějovicích (od roku 2006), členem Komise VEGA (od roku 2020), Humanitní komise APVV (od roku 2018), redakční rady časopisu Slavica litteraria, vydávaného Filozofickou fakultou Masarykovy univerzity v Brně (od roku 2019), místopředsedou Česko-slovenské asociace pro srovnávací literaturu (registrované při AILC v Paříži). Svého času pracoval v Grantové agentuře AV ČR, kde 
byl předsedou (2006-2012), našly by se ještě další časopisy, v jejichž redakčních radách působí nebo působil a jež dokládají uznání vědeckou komunitou. $V$ současnosti je na vrcholu tvůrčích sil, publikuje v periodikách registrovaných v prestižních databázích a připravuje další a další publikace a projekty v ČR i SR. Přejme mu další úspěchy, nové publikace a plodnou činnost ve prospěch mezinárodní slavistiky, komparatistiky a literární vědy.

Ivo Pospíšil

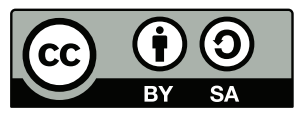

Toto dílo Ize užít v souladu s licenčními podmínkami Creative Commons BY-SA 4.0 International (<https:// creativecommons.org/licenses/by-sa/4.0/legalcode>). Uvedenése nevztahuje na díla či prvky (např. obrazovou či fotografickou dokumentaci), které jsou v díle užity na základě smluvní licence nebo výjimky či omezení príslušných práv.

https://doi.org/10.5817/OS2021-1-9

\section{Strážce rodu Vančurů. K sedmdesátinám Jiřiho Poláčka}

Roku 2020 si Jiří Poláček (narozen 13. března 1951 v Jablonném v Podještědí) vydal literárněhistorický bibelot s názvem Bratři Čapkové. Obsahuje sedm drobných př́spěvků o obou bratřích - ale nemylme se, Čapkové zdaleka nestáli a nestojí v popředí jeho zájmu. Ten byl vždycky namířen na jinou dvojici, ne sice bratrskou, ale rodovou na př́slušníky rodu Vančurů, na Antonína a Vladislava, z nichž první pojal pseudonym Jiří Mahen. Dědové obou těchto Vančurů byli bratřii a Vladislav Vančura oslovoval Mahena jako strýce.

Oběma tvůrcům věnoval Poláček pozornost už v sedmdesátých letech. O Vančurovi poprvé psal roku 1976 v Rovnosti (16. listopadu 1976), tehdy o jeho povídkách. O Mahenovi se poprvé vyjádřil o tři roky později, opět v Rovnosti (19. května 1979), stalo se tak $\mathrm{k}$ čtyřicátému výročí smrti čáslavského rodáka. $\mathrm{V}$ brněnské Rovnosti Poláček delší dobu redaktoroval.

O svém vztahu k Vančurovi se Poláček vyjádřil v rozhovoru s Jiří Rambouskem, uvedl tehdy: „Už jako studenta mě svým dílem i osobností uchvátil Vladislav Vančura. Věnoval jsem se dobovému kritickému ohlasu jeho próz - nejprve v diplomové práci a poté i v práci rigorózní. Také titul kandidáta věd jsem získal na základě vančurovské studie nazvané Postavy v próze Vladislava Vančury; v roce 1994 jsem ji vydal knižně pod názvem Portréty a osudy“ (Universitas 44, 2011, č. 1).

Poláček ve zmíněné monografii vystihuje především Vančurovy postavy. Při jejich líčení je přiléhavý, takto napřx. popisuje protagonistu jeho prvního románu: „Marhoulovo vnitřní ustrojení má v jádře konstantní podobu. Pod nárazy objektivní skutečnosti se mění jen zdánlivě nebo dočasně, podstatné změny doznává až v závěru 